\title{
Electrophoretic Studies of Australasian, North American and European Isolates of Sclerotinia sclerotiorum and Related Species
}

\author{
By A.-L. WONG AND H. J. WILLETTS \\ School of Botany, University of New South Wales, \\ Kensington, New South Wales 2033, Australia
}

(Received 5 May 1975)

\begin{abstract}
SUMMARY
Forty-seven isolates of Sclerotinia species, collected from a variety of crops growing in Australia, New Zealand, North America and Europe, have been classified into three distinct groups on the electrophoretic patterns for soluble proteins, arylesterase, acid phosphatase, tetrazolium oxidase, glucose-6-phosphate dehydrogenase (NADP-linked) and reduced nicotinamide adenine dinucleotide phosphate dehydrogenase. There were only small intra-group differences. The electrophoretic patterns of an isolate of Whetzelinia (=Sclerotinid) tuberosa were characteristically different from those of the other isolates. These results support the findings from previous studies when ontogenetic, electrophoretic and mycelialinteraction criteria were used to group a smaller number of isolates from New South Wales, Australia. It is concluded that $S$. sclerotiorum, S. trifoliorum and $S$. minor are three distinct species.
\end{abstract}

\section{INTRODUCTION}

Our ontogenetic (Willetts \& Wong, 1971), electrophoretic, and mycelial-interaction (Wong \& Willetts, 1973, 1975) studies of Sclerotinia sclerotiorum (Lib.) de Bary [=Whetzelinia sclerotiorum (Lib.) Korf \& Dumont, 1972] and related species, have consistently suggested that this group of fungi comprises three distinct species, S. minor, S. trifoliorum and S. sclerotiorum, although Purdy (1955), who used morphological criteria, included the three in the one species $S$. sclerotiorum. In earlier work we used fifteen isolates of Sclerotinia obtained from various crops growing in New South Wales, Australia. Analyses of isolates from a wider variety of crops, including more forage and vegetable legumes from other parts of Australia and the northern hemisphere, were needed before our conclusions from the New South Wales material could be generally applied to these fungi. This paper describes polyacrylamide gel electrophoretic studies on isolates collected from crops growing in four Australian states, and from New Zealand, North America and Europe.

\section{METHODS}

Forty-eight isolates of Sclerotinia were obtained from the Australian states of New South Wales, Victoria, Western Australia and Tasmania, and from New Zealand, the U.S.A., Canada, England and Switzerland (Table I).

The isolates were grown on Oxoid's modified Czapek Dox agar, supplemented with L-asparagine $(2 \mathrm{~g} / \mathrm{l})$ and thiamine hydrochloride $(2 \mathrm{mg} / \mathrm{l})$. The techniques used for culturing the fungi, protein extractions and I8-slot horizontal flat-bed polyacrylamide gel electrophoresis have been published (Wong \& Willetts, 1973). 
Table I. Isolates of Sclerotinia spp.

$\begin{array}{ll}\text { Isolate } & \text { Size of } \\ \text { Code } & \text { sclerotium* }\end{array}$

Host from which isolated

\begin{tabular}{ll} 
M & Sunflower \\
M & Tomato \\
M & Potato \\
M & Sunflower \\
L & Lucerne \\
L & Lucerne \\
L & French bean \\
L & French bean \\
L & Cauliflower \\
L & Cabbage \\
L & Sunflower \\
L & Capsicum \\
L & Anemone \\
L & Stock \\
L & Cauliflower \\
L & Soybean \\
L & Crimson clover \\
L & Soybean \\
L & Rape \\
M & Tomato \\
M & Unknown \\
M & Soybean \\
L & Soybean \\
M & Suckling clover \\
M & New Zealand blue lupin \\
L & Lupin \\
M & White lupin \\
M & Subterranean clover \\
L & Lettuce \\
L & French bean \\
L & White clover \\
L & Tomato \\
M & Tomato \\
LL & Bush bean \\
L & Anemone \\
M & Lettuce \\
M & Unknown \\
L & Centaurea sp. \\
L & Lettuce \\
L & Clover \\
\hline to & Th \\
\hline
\end{tabular}

$\begin{array}{lc}\begin{array}{l}\text { Place of } \\ \text { origin† }\end{array} & \begin{array}{c}\text { Year } \\ \text { isolated }\end{array} \\ \text { N.S.W. } & 1950 \\ \text { N.S.W. } & 1944 \\ \text { N.S.W. } & 1971 \\ \text { N.S.W. } & 1971 \\ \text { N.S.W. } & 1969 \\ \text { N.S.W. } & 1970 \\ \text { N.S.W. } & 1970 \\ \text { N.S.W. } & 1969 \\ \text { N.S.W. } & 1969 \\ \text { N.S.W. } & 1969 \\ \text { N.S.W. } & 1969 \\ \text { N.S.W. } & 1970 \\ \text { N.S.W. } & 1970 \\ \text { N.S.W. } & 1969 \\ \text { N.S.W. } & 1969 \\ \text { N.S.W. } & 1972 \\ \text { N.S.W. } & 1971 \\ \text { N.S.W. } & 1973 \\ \text { Vic. } & 1973 \\ \text { Vic. } & 1973 \\ \text { N.S.W. } & 1973 \\ \text { N.S.W. } & 1973 \\ \text { N.S.W. } & 1973 \\ \text { W.A. } & 1961 \\ \text { W.A. } & 1971 \\ \text { W.A. } & 1971 \\ \text { W.A. } & 1972 \\ \text { Vic. } & 1973 \\ \text { Vic. } & 1974 \\ \text { N.S.W. } & 1973 \\ \text { Tas. } & 1973 \\ \text { N.Z. } & - \\ \text { N.Z. } & - \\ \text { U.S.A. } & - \\ \text { Switz. } & 1972 \\ \text { U.S.A. } & - \\ \text { Can. } & 1936 \\ \text { Can. } & 1971 \\ \text { Eng. } & 1970 \\ \text { Eng. } & 1970\end{array}$

Source

Isolates used by Wong $\&$ Willetts (1973)

D. Letham (isolate U)

D. Letham (isolate N)

V. Patchanee

P. Merriman

P. Merriman

V. Patchanee

R. Keogh

R. Keogh

G. C. MacNish (C278)

G. C. MacNish (WAI469)

G. C. MacNish

G. C. MacNish

R. Price

P. Merriman

City market

P. J. Sampson

B. T. Hawthorne

B. T. Hawthorne

R. P. Korf (Lorbeer 73-6)

R. P. Korf

R. P. Korf

M. E. Elliott (599)

M. E. Elliott (84I)

C. Booth (IMI 48268 )

C. Booth (IMII47202)

* M, small (0.3 to $2 \mathrm{~mm}$ ); L, large (I to $8 \mathrm{~mm}$ ); LL, large (2 to $15 \mathrm{~mm}$ ).

$\dagger$ N.S.W., New South Wales, Australia; Vic., Victoria, Australia; W.A., Western Australia; Tas., Tasmania, Australia; N.Z., New Zealand; U.S.A., United States of America; Switz., Switzerland; Can., Canada; Eng., England.

Soluble proteins and five enzymes were studied. Proteins were stained with Coomassie blue (Chrambach et al. 1967); reduced nicotinamide adenine dinucleotide phosphate (NADPH) dehydrogenase (EC. I.6.99. I) was stained in an incubation medium containing $50 \mathrm{ml} 0.05 \mathrm{M}$-tris-glycine buffer, $\mathrm{pH} \mathrm{8.3,20} \mathrm{mg} \mathrm{nitroblue} \mathrm{tetrazolium,} \mathrm{and} 25 \mathrm{mg}$ NADPH; tetrazolium oxidase was detected by the method of Vrba \& Zampa (1973), and arylesterase (EC. 3.I.I.2), acid phosphatase (EC. 3.1.3.2) and NADP-linked glucose-6-phosphate dehydrogenase (EC. I . I . I .49) by the methods outlined by Cole, Blondin \& Temple (1968).

The electrophoretic patterns of the soluble proteins and five selected enzymes were repeated at least three times for each isolate. 

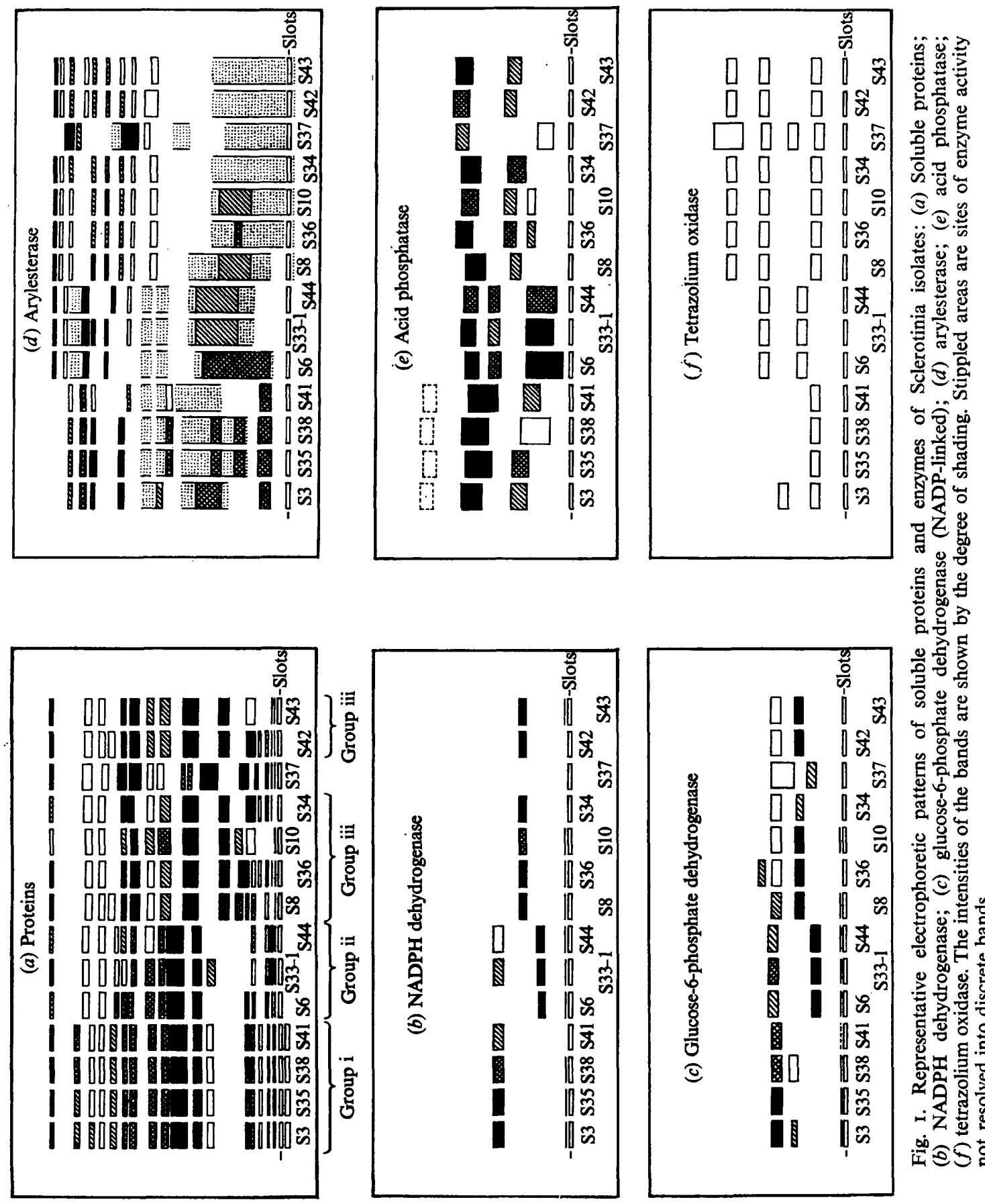

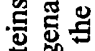

응

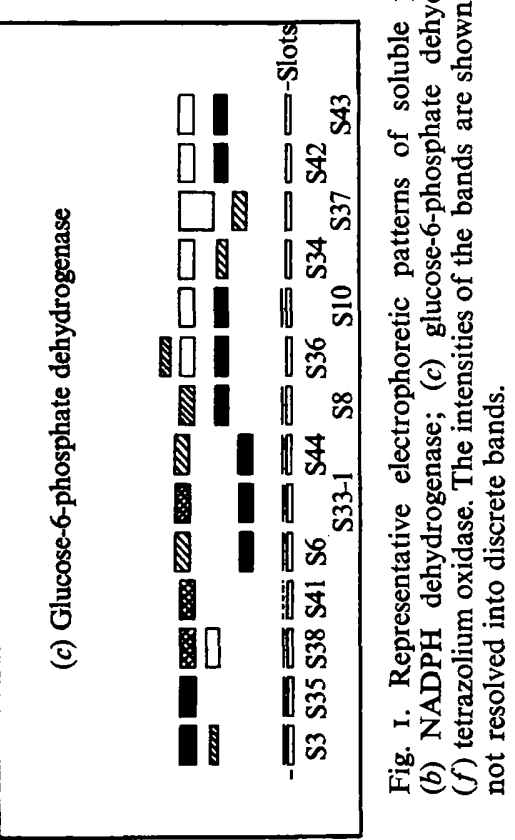


Table 2. Grouping of Sclerotinia isolates based on electrophoretic patterns of general proteins and five enzymes

\begin{tabular}{|c|c|c|c|}
\hline Group & Isolates & $\begin{array}{c}\text { Size range of } \\
\text { sclerotia (on PDA) }\end{array}$ & Host-range \\
\hline I & $\begin{array}{l}\mathrm{s} I, \mathrm{~s} 2, \mathrm{~s} 3, \mathrm{~s} 4, \mathrm{~s} 2 \mathrm{I}, \mathrm{s} 22, \mathrm{~s} 23, \mathrm{~s} 25 \\
\mathrm{~s} 26, \mathrm{~s} 28, \mathrm{~s} 29, \mathrm{~s} 35, \mathrm{~s} 38, \mathrm{~s} 4 \mathrm{I}\end{array}$ & Small (0.3-2 mm) & $\begin{array}{l}\text { Sunflower, tomato, potato, } \\
\text { lettuce, soybean, clover, lupin, } \\
\text { unknown hosts }\end{array}$ \\
\hline 2 & s6, s7, s33/I-9, s44 & Large ( $1-8 \mathrm{~mm})$ & Lucerne, clover \\
\hline 3 & $\begin{array}{l}\text { s8, s9, sio, si I, si2, si 3, si4, si 5, } \\
\text { si6, si 7, si8, si9, s20, s24, s27, } \\
\text { s31, s32, s34, s36, s42, s43 }\end{array}$ & Large ( $\mathrm{I}-8 \mathrm{~mm})$ & $\begin{array}{l}\text { Cauliflower, cabbage, sunflower, } \\
\text { capsicum, anemone, lettuce, } \\
\text { stock, tomato, Centaurea sp., } \\
\text { rape, French bean, soybean, } \\
\text { bush bean, clover, lupin }\end{array}$ \\
\hline 4 & s37 & Large $(2-15 \mathrm{~mm})$ & Anemone \\
\hline
\end{tabular}

\section{RESULTS}

Representative electrophoretic patterns for soluble proteins and the five enzymes of fourteen isolates selected from a wide geographical area and a variety of hosts are given as interpretative drawings (Fig. I). With the exception of isolate 537 , which was supplied by R. P. Korf as Whetzelinia tuberosa, the isolates form three distinct groups (Table 2).

Group 1 . The fourteen isolates of this group were obtained from a wide host-range and produced small sclerotia. Their protein patterns were almost identical and each had a cathodic band which was absent from the patterns of the other isolates. Some intra-group variations occurred with arylesterase, glucose-6-phosphate dehydrogenase and tetrazolium oxidase. The variations were greatest with arylesterase patterns, which could not be used on their own to group a number of isolates. Some isolates showed an additional but minor band for glucose-6-phosphate dehydrogenase and tetrazolium oxidase, but otherwise the patterns were very similar. The patterns for NADPH dehydrogenase and acid phosphatase were very uniform.

Group 2. Twelve large-sclerotium producing isolates from lucerne and clover were included in this group. The protein and enzyme patterns were similar; variations in the protein patterns were mainly confined to the minor bands. There were some qualitative differences in the electrophoretic patterns for arylesterase and NADPH dehydrogenase, but the differences were relatively minor.

Group 3. Twenty-one large-sclerotium forming isolates from vegetable and forage legumes and non-legumes were included in this group. Some intra-group differences in protein patterns were observed in the region of the slow-moving bands. At least two bands for acid phosphatase were detected for most of the isolates, with an additional slow-moving one for some. Most isolates had two bands of glucose-6-phosphate dehydrogenase, but a few had an additional fast-moving one. The NADPH dehydrogenase and the tetrazolium oxidase patterns were very uniform.

The isolate from anemone sent to us by R. P. Korf as $W$. tuberosa (s37) produced electrophoretic patterns for tetrazolium oxidase which were similar in some respects to those produced by group 3 isolates. All other patterns for $\$ 37$ were markedly different from the corresponding ones of the other isolates. 


\section{DISCUSSION}

These results indicate that, apart from the one culture of $W$. tuberosa, the isolates analysed can be classified into three distinct groups. The intergroup electrophoretic differences were consistent and there were no apparent exceptions. As the isolates were obtained from a wide geographical area and a variety of host plants, they constitute a reasonably representative world and crop sample. The grouping agrees with our previous findings when other criteria were used (Willetts \& Wong, 1971; Wong \& Willetts, 1975). We suggest that the isolates in groups I, 2 and 3 (Table 2) correspond to three distinct species, S. minor, S. trifoliorum and S. sclerotiorum respectively.

The relatively small amount of variability of intra-group electrophoretic patterns suggests that there are no further major taxonomic sub-divisions within the three species. Keay (1939) and Loveless (195I) observed differences between isolates of Sclerotinia obtained from forage legumes and from beans. They concluded that the fungus parasitizing forage legumes is $S$. trifoliorum, while that on beans is a distinct subspecies, $S$. trifoliorum var. fabae. The electrophoretic patterns and mycelial interactions of bean isolates are the same as those produced by isolates of $S$. sclerotiorum. It appears that the host range of $S$. trifoliorum is confined to forage legumes, while $S$. minor and $S$. sclerotiorum have wide host ranges which include both vegetable and forage legumes. Thus, the use of host association is not a reliable taxonomic criterion for the three species.

There has been some controversy regarding the presence of $S$. trifoliorum in Australia. Isolate $\mathbf{4 4} 4$ was obtained from the Commonwealth Mycological Institute as a culture of $S$. trifoliorum. Electrophoretically, s44 is very similar to isolates s6 and s7 from New South Wales and to $533 / \mathrm{I}-9$ from Tasmania. These results provide evidence that $S$. trifoliorum parasitizes crops in Australia.

We are very grateful to the Australian and overseas workers, listed in Table I, who supplied us with cultures of Sclerotinia spp. We thank Dr R. J. W. Byrde for his critical reading of the manuscript, and the Reserve Bank of Australia for financial support.

\section{REFERENCES}

Chrambach, A., Reisfeld, R. A., Wyckoff, M. \& ZaCCari, J. (1967). A procedure for rapid and sensitive staining of protein fractionated by polyacrylamide gel electrophoresis. Analytical Biochemistry 20, I50-I 54.

Cole, F. E., Blondin, J. \& Temple, L. (1968). Enzyme patterns during a synchronous growth cycle of Chlorella pyrenoidosa. Cell and Tissue Kinetics 1, 281-288.

KeAY, M. A. (1939). A study of certain species of the genus Sclerotinia. Annals of Applied Biology 26, $227-246$.

KoRf, R. P. \& Dumont, K. P. (1972). Whetzelinia, a new generic name for Sclerotinia sclerotiorum and S. tuberosa. Mycologia 64, 248-25I.

Loveless, A. R. (I95I). The confirmation of the variety fabae Keay of Sclerotinia trifoliorum Eriksson. Annals of Applied Biology 39, 252-275.

PuRDY, L. H. (1955). A broader concept of the species Sclerotinia sclerotiorum based on variability. Phytopathology 45, 42I-427.

VRBA, M. \& ZAMPA, P. (1973). Interspecies variation of tetrazolium oxidase electrophoretic patterns in mycobacteria. Folia microbiologica (Praha) 18, 32-39.

WilletTs, H. J. \& Wong, A.-L. (197I). Ontogenetic diversity of sclerotia of Sclerotinia sclerotiorum and related species. Transactions of the British Mycological Society 57, 515-524.

WoNG, A.-L. \& WILlETTs, H. J. (1973). Electrophoretic studies of soluble proteins and enzymes of Sclerotinia species. Transactions of the British Mycological Society 6r, 167-178.

Wong, A.-L. \& Willetrs, H. J. (1975). A taxonomic study of Sclerotinia sclerotiorum and related species: mycelial interactions. Journal of General Microbiology 88, 339-344. 